\title{
KOMUNITAS MUSIK DI BSD
}

\author{
Yabez Koernia ${ }^{1)}$, Tony Winata ${ }^{2)}$ \\ 1)Program Studi S1 Arsitektur, Fakultas Teknik, Universitas Tarumanagara, yabezk@gmail.com \\ 2) Program Studi S1 Arsitektur, Fakultas Teknik, Universitas Tarumanagara, tonywinata@ft.untar.ac.id
}

\begin{abstract}
Abstrak
Generasi milennial sangat pintar dalam menggunakan internet sebagai media sosial maupun sebagai media belajar. Dalam penggunaan internet ini mereka belajar dengan sarana satu arah pembelajaran, hal tersebut membuat sebagian besar pembelajaran dapat salah kaprah dari teknik membaca maupun bermain musik. Hal yang perlu diperhatikan adalah detail kecil seperti membaca balok piano maupun bermain sesuai tangga nada yang benar dan hal tersebut hanya ada bila belajar dengan pembelajaran 2 arah seperti sekolah, namun millennial tidak menyukai dengan adanya sekolah formal, yang ada sekarang ini tetapi mereka ingin belajar dengan bebas dimana mereka dapat bermain bebas dan juga dapat bermain bersama tanpa adanya kurikulum yang membuat mereka seperti ditahan Dalam hal ini maka diperlukan sebuah sekolah informal yang dapat menampung para musisi millennial sekarang ini dan juga menjadi sebuah tempat untuk dapat berkumpul dan juga belajar bersama oleh karena itu dibutuhkan sebuah komunitas informal yang dapat menampung keinginan dan kreatifitas untuk kegiatan para millennial.
\end{abstract}

Kata kunci: komunitas; milenial; musik

\begin{abstract}
The millennial generation is very smart in using the internet as social media and as a learning media. In using this internet they learn with a one-way learning tool, which makes most of the learning misguided from the techniques of reading and playing music. Things that need to be considered are small details such as reading piano beams or playing according to the correct scales and that only exists when learning with 2-way learning such as schools, but millennials don't like the existence of formal schools, which exist today but they want to learn with free where they can play freely and also be able to play together without a curriculum that makes them like being detained. In this case an informal school that can accommodate millennial musicians is now needed and also a place to gather and also learn together therefore an informal community is needed that can accommodate the desire and creativity for the activities of the millennials.
\end{abstract}

Keywords: community; music; millenials

\section{PENDAHULUAN}

Di Indonesia, proporsi generasi millenial sekitar 34,45 persen, lebih dari sepertiga jumlah penduduk negeri ini. Dari kajian beberapa peneliti, generasi millenial cenderung unik dibandingkan generasi-generasi sebelumnya. komposisi penduduk Indonesia, 90 juta millenial (20-34 tahun), dengan total fertility rate (angka kelahiran) 2,28 (per 1.000 orang per tahun), dan angka kematian anak 24 (per 1.000 kelahiran), meski angka harapan lama sekolah masih 12,72 tahun.

Ciri yang menjelaskan Milennial adalah generasi yang terkoneksi satu sama lainnya dalam kategori ini dapat terlihat bahwa hal tersebut yang diminati oleh konsumen masyarakat di Indonesia (datanya terungkap dari google trace) disimpulkan bahwa masyarakat Indonesia lebih senang terhadap genre yang menghibur atau entertainment. Dalam genre tersebut juga memperlihatkan bahwa dengan internet membuat semua dapat terhubung dimanapun dan kapanpun. Dari karakter / cara berkerja mereka cenderung lebih dua arah pembelajaran. Dengan menggunakan media internet maupun dengan buku yang sekarang ini dengan mudah kita dapati. hal tersebut membuat sebagian 
besar pembelajaran menjadi salah kaprah dari teknik membaca maupun bermain musik. Hal yang perlu diperhatikan adalah detail kecil seperti membaca balok piano maupun bermain sesuai tangga nada yang benar dan hal tersebut hanya ada bila belajar dengan pembelajaran 2 arah seperti sekolah, namun millennial tidak menyukai dengan adanya sekolah formal.

Musik formal sudah mulai berkembang sejak zaman manusia mulai berkumpul dimana mereka dapat berkumpul bermain bersama dan juga dapat belajar bersama Hal ini sudah berkembang di UK dimana pada tahun 1960 mereka sudah mulai mempraktekan hal ini dimana mereka bermain bersama dalam komunitas musik pada sekolah musik yang nantinya dapat berkembang juga di Indonesia. Dalam lingkup yang paling kecil, komunitas musik berperan sebagai tempat pertukaran ilmu antar anggotanya. Melalui kegiatan perkumpulan dan pertemuan rutin, masing-masing anggota dapat saling bertukar ilmu serta pengalaman mereka.

Dengan latar belakang masing-masing anggota yang berbeda-beda, baik dari orang yang kurang mengerti musik, dapat menjadi referensi-referensi baru bagi anggota lainnya. Barangkali, cerita dari teman sekomunitas bisa menjadi motivasi yang lebih bagi yang lain dalam menggeluti musik. Komunitas musik juga berfungsi sebagai sarana silaturahmi antar sesama musisi. Jangkauan relasi adalah hal yang lumayan penting bagi musisi era sekarang, di mana persaingan pasar sudah sedemikian sengitnya, sehingga diperlukan komunitas musik di Indonesia.

\section{KAJIAN LITERATUR}

\section{Sejarah Komunitas Musik}

Komunitas adalah sekelompok orang yang saling peduli satu sama lain lebih dari yang seharusnya, dimana dalam sebuah komunitas terjadi relasi pribadi yang erat antar para anggota komunitas tersebut karena adanya kesamaan interest atau values. Inggris telah menjadi pemain nasional penting dalam pengembangan praktik musik komunitas. Di Inggris komunitas musik berkembang secara luas sejak 1960-an dan memiliki periode berkembang yang signifikan pada 1980-an. Musik komunitas secara nasional dan internasional telah membangun serangkaian praktik, repertoar, infrastruktur organisasi, kualifikasi, dan jalur karier. Ada unsur-unsur inovasi budaya dan pedagogis yang bisa diperdebatkan dalam komunitas musik.

Komunitas musik diakui sebagai fitur penting yang secara rutin didanai dalam pembuatan dan pengajaran musik di Inggris saat ini, dan gerakan terkemuka dalam praktik kontemporer seni komunitas. Ini memiliki struktur nasional yang meliputi zona aksi musik; organisasi regional penting (CM, Community Music East, More Music, SAGE) dan Music Leader; inovasi berkelanjutan dan eksperimen yang didanai (In Harmony / El Sistema); dan, tak terkecuali, suatu kelompok yang signifikan dan mapan dari para profesional freelance yang berdedikasi yang bekerja sebagai musisi komunitas sebagai bagian dari karier musik kreatif mereka.

Tabel 1. Tipologi / karakteristik bentuk Teater Musik

\begin{tabular}{|l|c|}
\hline Plan form & Dates \\
\hline \hline Shoebox/rectangular plan & $1850-1905,1970-$ present \\
\hline Theatre form & $1850-1935$ \\
\hline Fan-shaped plan & $1925-1985$ \\
\hline Terraced hall & $1960-$ present \\
\hline
\end{tabular}

Sumber: Mike Baroon, Proceedings of the Institute of Acoustics,2006

Data diatas merupakan bentuk teater musik yang memiliki tren sesuai dengan tahun- tahun bentuk arsitektur dasar teater musik adalah persegi panjang atau kotak Sepatu, dengan dinding sisi paralel dan dua balkon yang berjalan di belakang dan di sepanjang sisi dinding. 
Langit-langit tinggi di $19 \mathrm{~m}$ untuk memberikan gema tepat waktu. Desain ini sangat dalam tradisi Eropa 19th abad ke aula, dengan hiasan plester diterapkan untuk dinding dan langitlangit yang kita ketahui sekarang. Namun dengan seiringnya berjalan waktu hal tersebut berubah dikarenakan pencapaian pantulan suara yang sempurna sehingga memiliki bentuk yang semakin lama menjadi tercampur aduk menciptakan bentuk yang baru dan juga membuat semua suara dapat terpantulkan secara sempurna. Pada lembar berikut ini tertera hasil kajian pantulan suara yang baik dari bentuk tipologi yang ada. Berdasarkan riset tipologi yang ada bentuk mempengaruhi beberapa hal namun yang terutama adalah titik fokus dan juga pantulan suara yang baik berikut adalah riset dari tipologi.

Tabel 2. Riset Tipologi Bentuk Theater

\begin{tabular}{|c|c|c|}
\hline 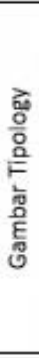 & 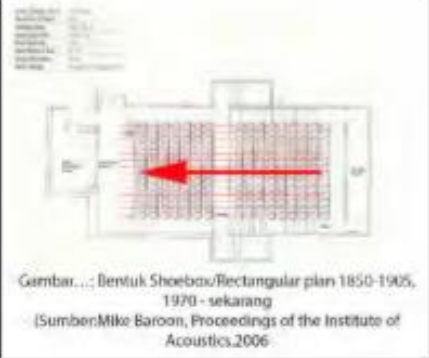 & 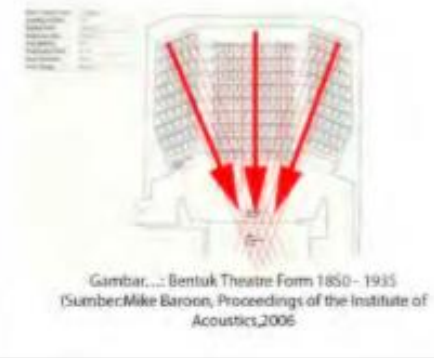 \\
\hline 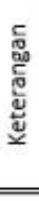 & $\begin{array}{l}\text { Bentuk Shoebox / Rectangular } \\
\text { yang terkenal era } 1850 \text { - } 1905 \& 1970-2000 \\
\text { ruangan ini sangat banyak dipakai sampai } \\
\text { sekarang untuk menghemat bentuk ruang } \\
\text { namun mempunyai kelemahan pada titik } \\
\text { folkus dan sekarang menjadi ruang } \\
\text { serbaguna. }\end{array}$ & $\begin{array}{l}\text { Bentuk Theater Form } \\
\text { yang terkenal era } 1850 \text { - } 1935 \\
\text { Bentuk ini adalah bentuk yang } \\
\text { disempurnakan dari bentuk kotak dimana } \\
\text { arsiteknya ingin penonton memiliki fokus } \\
\text { lurus satu titik. }\end{array}$ \\
\hline 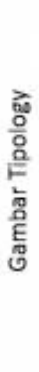 & 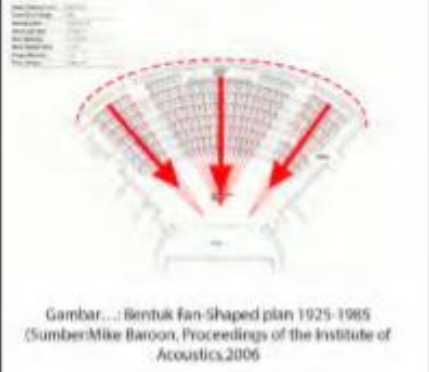 & 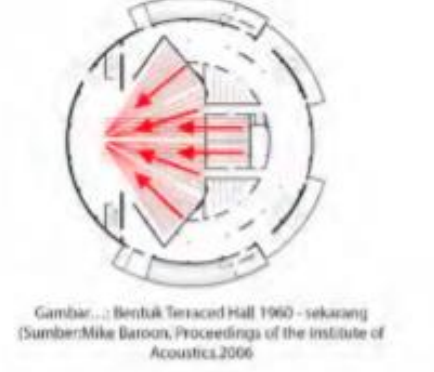 \\
\hline 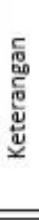 & $\begin{array}{l}\text { Bentuk Fan Shape / Kipas } \\
\text { yang terkenal era } 1925 \text { - } 1985 \\
\text { Bentuk ini memiliki bentuk dengan suara dan } \\
\text { titik fokus yang baik namun bentuknya } \\
\text { membuat banyak ruang mati dan bentuknya } \\
\text { setengah lingkaran yang membuat } \\
\text { bangunan menjadi mahal. }\end{array}$ & $\begin{array}{l}\text { Bentuk Terraced hall / Teras } \\
\text { yang terkenal era } 1960 \text { - sekarang } \\
\text { Bentuk ini memiliki bentuk dengan suara dan } \\
\text { titik fokus yang paling baik dengan teras } \\
\text { yang mampu membuat jumlah kursi yang } \\
\text { lebih banyak dan pantulan suara paling } \\
\text { bagus oleh karena itu dipakai sampai } \\
\text { sekarang ini. }\end{array}$ \\
\hline
\end{tabular}

Sumber: Penulis, 2019

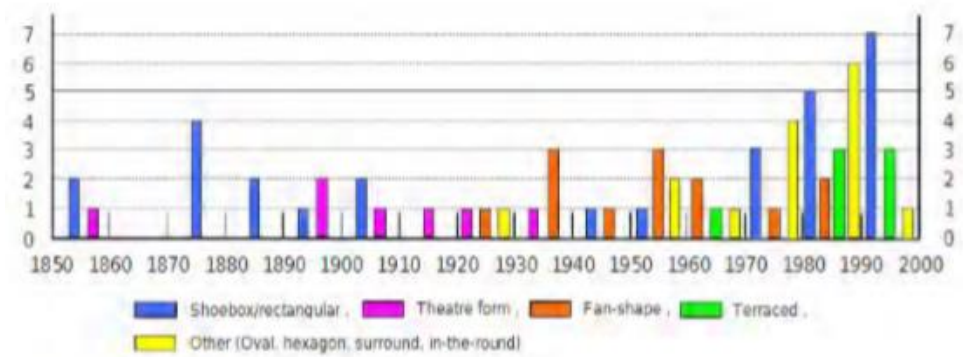

Gambar 1. Tren tipologi dari sejarah musik

Sumber: Mike Baroon, Proceedings of the Institute of Acoustics, 2006 
Dalam graphic tersebut dapat dilihat bahwa sejarah musik berulang-ulang untuk menghasilkan akustik music yang sempurna namun dapat dilihat bahwa pada tahun 1990 merupakan bentuk terbaik yaitu shoebox/rectangular yang memiliki fungsi serbaguna dan dapat dipakai beragam macam fungsi, pada tahun terakhir tipologi menunjukan bahwa bentuk yang bercampur menciptakan sebuah harmonisasi suara yang baik dan juga membuat sebuah ruangan tidak monoton.

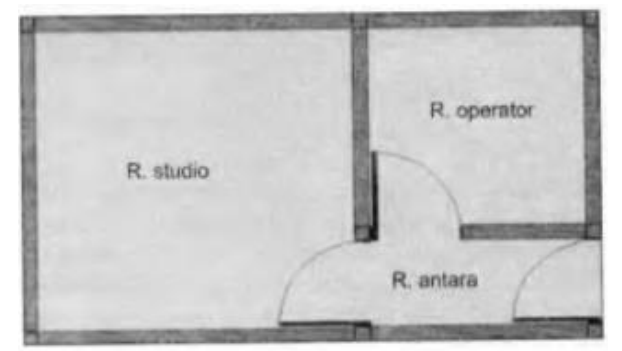

Gambar 2. Bentuk unit terkecil dalam studio musik Sumber: Penulis, 2019

Studio rekaman adalah tempat dimana para pelaku musik dapat merekam karya musik dari bermacam-macam jenis alat musik yang dipadukan menjadi satu sehingga menjadi sebuah musik (lagu) dengan hasil yang maksimal. Seiring perkembangan teknologi digital, studio rekaman mengalami penyesuaian dari segi perangkat rekaman yang digunakan. Para musisi mencari cara untuk membuat semuanya serba cepat tanpa harus membuang waktu, tenaga dan biaya yang berlebihan. Penggunaan studio rekaman yang didukung dengan perangkat digital dapat membantu para musisi semakin mudah untuk meproduksi karya musik secara efektif dan efisien.

Seringkali, akan ada ruangan yang lebih kecil yang disebut "bilik isolasi" untuk mengakomodasi instrumen keras seperti drum atau amplifier dan speaker gitar listrik, untuk menjaga agar suara ini tidak dapat didengar oleh mikrofon yang menangkap suara dari instrumen atau suara lain, atau untuk menyediakan Kamar "kering" untuk merekam vokal atau instrumen akustik yang lebih tenang seperti gitar akustik atau biola. Studio rekaman besar biasanya memiliki berbagai instrumen dan peralatan musik yang besar, berat, dan sulit diangkut, seperti piano besar, organ Hammond, dan piano listrik.

\section{Community Music for Millenials}

Komunitas Musik bertujuan menyediakan wadah bagi para musisi dan komunitas pecinta musik yang dapat mengakomodasi kebutuhan mereka secara maksimal. Dengan adanya wadah ini diharapkan dapat memudahkan mereka untuk dapat berinteraksi serta tercipta rasa kekeluargaaan terhadap komunitas musik ini. Dalam komunitas ini juga milenial dapat bermain dan bermain bersama sehingga menjadi sebuah komunitas yang erat.

\section{Ingin Mendapatkan Segala Sesuatu Dengan Cepat Dan Mudah}

Millenial berpikir untuk mencari lebih mudah seperti contohnya, mengapa harus datang ke kantor bila pekerjaan bisa dikirim dari via internet? Mengapa harus kuliah bila kemampuan saya lebih baik dibanding mereka yang punya ijazah? Mengapa tidak semua perusahaan memberikan asuransi kesehatan bagi karyawan? Ini contoh kecil tradisi yang "dirusak" oleh mereka. (https://www.alinea.id/nasional/pembahasan-ruu-permusikan-diharap-libatkanseluruh-musisib1WZL9hIY). Hal ini yang membuat dunia music menjadi tidak ada standar kualitas music lagi, dengan adanya pemikiran seperti ini dapat saja dengan mudah membuat music lalu dapat disebar dalam dunia internet dan berharap menjadi terkenal. Padahal pemusik yang lain memiliki proses persetujuan dari rekaman, labelling dan juga persejutan ikatan musik untuk dapat memperjual belikan lagu mereka. 


\section{Mereka Ingin Bersosialisasi}

Manusia millennial memiliki jiwa sosial yang tinggi, dan ingin dapat terhubung dengan rekan mereka baik di dalam dunia nyata ataupun di dunia maya. Mereka menikmati menjadi bagian dari komunitas yang terjalin erat yang terikat oleh hubungan yang kuat. Millennial juga sering mengekspresikan dirinya lewat interaksi sosial maupun dunia maya.Peran musik didunia berkembang pesat menjadikannya suatu keharusan dan konsumsi kita sehari-hari jadi tidak menutup kemungkinan musik kini meluas menjadi suat bahasa alat komunikasi bagi kita dan pula musik tidak mengenal kalangan atau ras siapapun bisa menikmati dan memahami.

\section{Perubahan Perilaku Manusia Terhadap Musik}

Musik yang sekarang sudah berbeda menurut buku Music Community music in the UK: Historical Perspective. Music sudah mulai berkembang dimana zaman manusia mulai berkumpul Bersama bermain musik dimana mereka dapat berkumpul bermain Bersama dan juga dapat belajar Bersama, hal ini sudah berkembang di UK dimana pada tahun 1960 mereka sudah mulai mempraktekan hal ini dimana mereka bermain Bersama dibandingkan diajarkan dan bila salah mereka tidak akan naik peringkat. Mereka mementingkan sebuah pengalaman dalam musik tersebut.

\section{METODE DAN ANALISIS}

Metode yang dipakai adalah dari buku Pattern Languange. Metode ini dipakai karena cocok dengan aktivitas dalam komunitas musik, dimana komunitas musik terbentuk dari ruang kosong yang akhirnya membentuk sebuah keramaian sehingga menciptakan sebuah nodes yang baru dengan metode Pattern Languange. Dalam Pattern Languange terdapat sebuah ilustrasi dimana sebuah perkumpulan dimana manusia melakukan aktivitas sehingga menciptakan sebuah ruang yang baru (Life). Ruang tersebut tercipta menjadi ramai sehingga tercipta aktivitas publik (Space). Aktivitas tersebut menciptakan sebuah keramaian dimana manusia menciptakan sebuah lingkungan dimana mereka hidup berkerja (Buildings). Berikut adalah ilustrasinya.
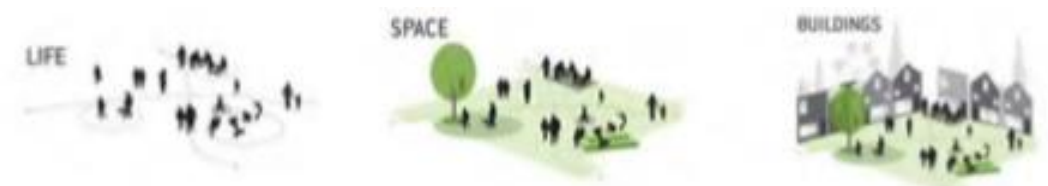

Gambar 3. Ilustrasi Activity Diagram

Sumber: https://www.visual-paradigm.com/what-is-activity-diagram

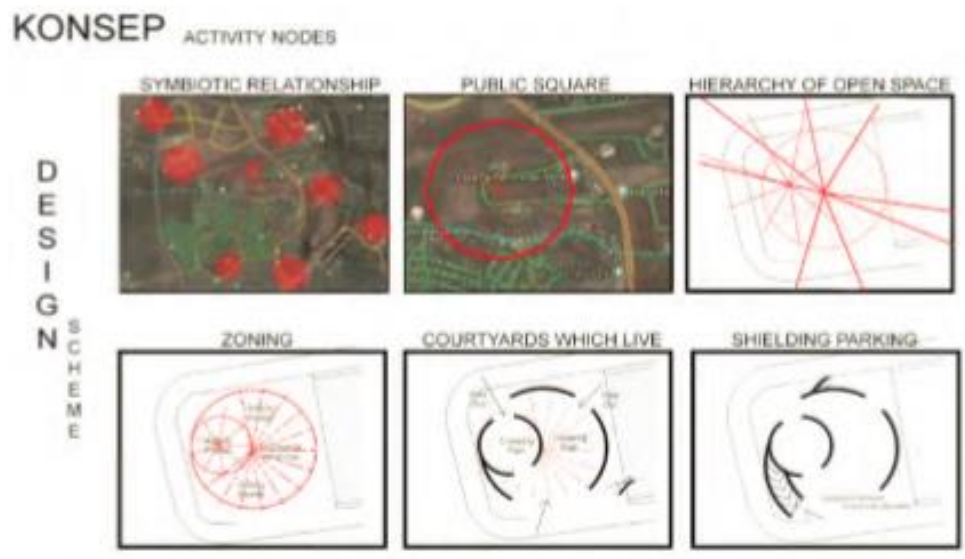

Gambar 4. Design Scheme Sumber: Penulis, 2019 
Dalam Pattern Langguange diambil 6 point penting yang dapat membantu dalam membuat bentuk bangunan dalam membentuk sebuah gubahan massa ini, yaitu Symbiotic Relationship, Public Square, Hirearchy Of Open Space, Zoning / Activity Pocket, Courtyard Which Live, dan Shielding Parking.

\section{Symbiotic Relationship}

Hal ini membicarakan tentang relasi terhadap semua fasilitas yang ada terhadap bangunan sekitarnya, untuk tahap ini dilihat sebuah tempat yang mempunyai lingkaran aktivitas disekitar tapak tersebut. Dalam daerah BSD ini terlihat 8 titik fasilitas yang berupa tempat sekolah, kuliner, perumahan, apartemen, taman bermain, perkantoran, gedung sewa, dan mall.

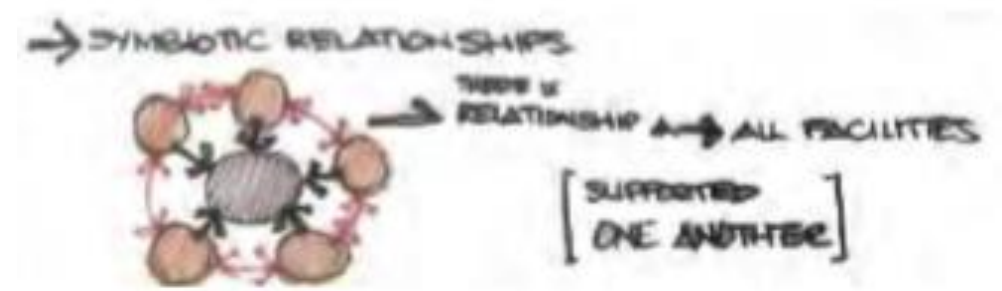

Gambar 5. Konsep Symbiolic Realtionship dalam Pattern Languange Sumber: Penulis, 2019

\section{Public Square}

Dalam public square ini terlihat bangunan terletak benar-benar dalam lingkaran tengah sebuah fasilitas yang ada pada bangunan. Fasilitas yang tersebut juga harus terkait dan dapat membantu sebuah bangunan yang ada.

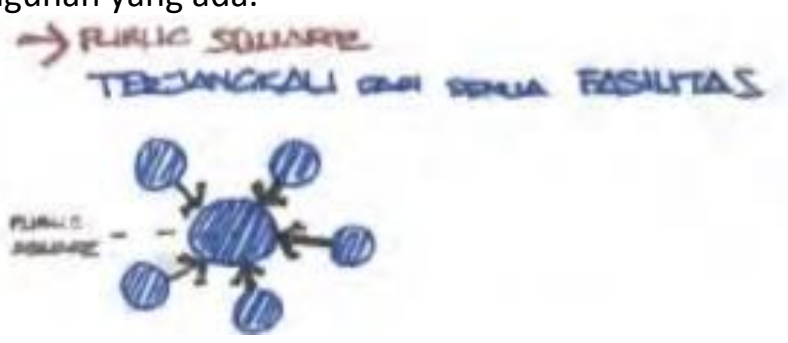

Gambar 6. Konsep Public Square dalam Pattern Languange

Sumber: Penulis, 2019

\section{Hirearchy Of Open Space}

Dalam sebuah ruang publik harus memiliki hirarki yang ada sehingga bangunan menjadi terarah antara sirkulasi dengan posisi ruangannya. Dalam bangunan ini terbagi menjadi 2 titik. Titik pertama yaitu sebuah public space dimana manusia dapat berkumpul dititik tengah dan juga titik kedua menjadi vocal point yang ada dalam bangunan tersebut.

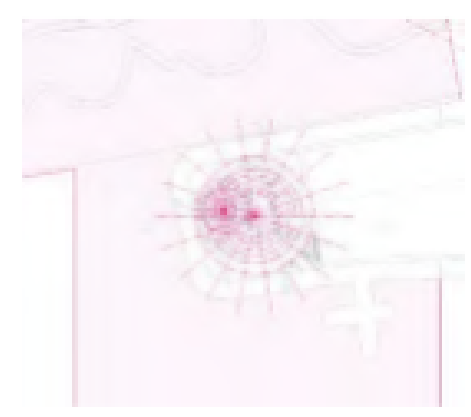

Gambar 7. Konsep Hirearchy Of Open Space dalam Pattern Languange Sumber: Penulis, 2019 


\section{Zoning / Activity Pocket}

Dalam Pattern Languange disebutkan beberapa aktivitas yang membuat pengunjung tertarik dalam bangunan :Toko, Retail, Kursi, Lapangan terbuka, Taman, dan Bangunan anti pagar.

\section{Courtyard Which Live}

Dalam tahap ini membuat bangunan menjadi lebih hidup dimana pengunjung harus dapat menembus sebuah jalan pada suatu tempat. Misalkan pada bagian utara bangunan terdapat sebuah taman kota, sirkulasi bangunan harus dapat melihat kea rah keluar sehingga bangunan terlihat sebuah aktivitas yang ramai.

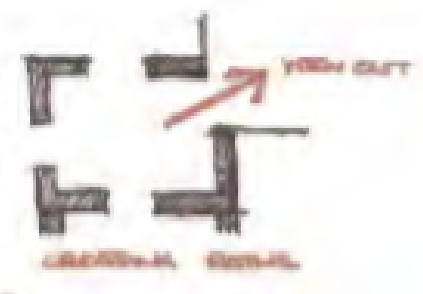

Gambar 8. Konsep Courtyard Which Live dalam Pattern Languange Sumber: Penulis, 2019

\section{Shielding Parking}

Parkir dan juga jalur mobil diusahakan tidak terlihat dapat juga dengan berbagai cara yaitu dinding alami seperti vegetasi, Lobby yang lebih lebar sehinga jalur pedestrian menjadi kesan lebih lebar, retail yang membuat pejalan kaki memiliki fokus yang berbeda.

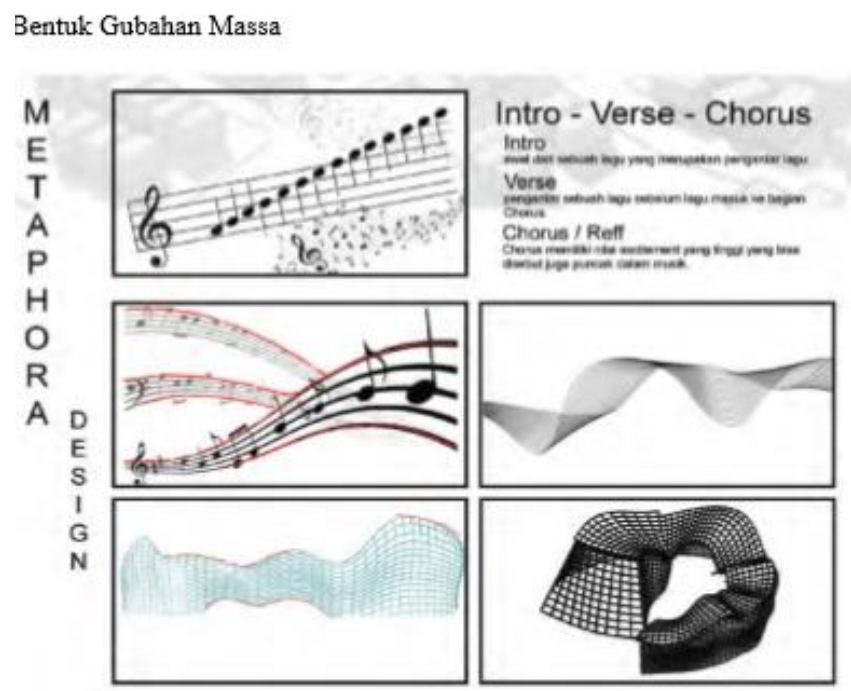

Gambar 9. Bentuk Metaphora gubahan massa Sumber: Penulis, 2019

Desain gubahan massa terbentuk dari Metaphora dimana bentuk tangga nada musik yang ada dibuat bermain seperti naik turunnya sebuah permainan musik. Lalu diambil diagram tersebut dan dibuat menjadi sebuah alunan naik turun. Dalam tangga balok tersebut not balok diibaratkan sebagai manusia yang ada di dalamnya dimana manusia tersebut bergerak menyamping membuat seperti iringan bayangan hitam bergerak. Lokasi Tapak berada di jalan Adiraksa Raya (Jakarta Selatan), Jalan Puri Ayu 1 (Jakarta Barat), dan Jalan Lengkong Barat (BSD). Lokasi ini dipilih berdasarkan:

a. Tinjauan terhadap struktur kota: berada pada kawasan yang strategis yang merupakan daerah yang mempunyai banyak sekali fasilitas yang dapat membantu bangunan untuk 
dapat meramaikan dan saling melengkapi.

b. Wilayah pengembangan: Berada di wilayah pengembangan pembangunan yang baru berkembang sehinngga melengkapi fasilitas lainnya.

c. Pencapaian dan aksesbilitas : dapat mudah diakses dari seluruh penjuru kota terutama melihat jalanan baru yang akan dibangun baik dari angkutan umum maupun mobil pribadi

\section{Program Ruang}

Komunitas Musik merupakan suatu program baru berdasarkan kurikulum negara Inggris yang didalamnya mengembangkan 3 jenis kegiatan yaitu sebuah tempat pelatihan studio Musik, Theater musik, Café musik, dan Modular Stage (Taman Musik). Titik utama yang akan menjadi menarik adalah taman musik yang disajikan langsung didepan penonton yang digunakan sebagai amphiteater kepada para startup musik maupun para pendengar

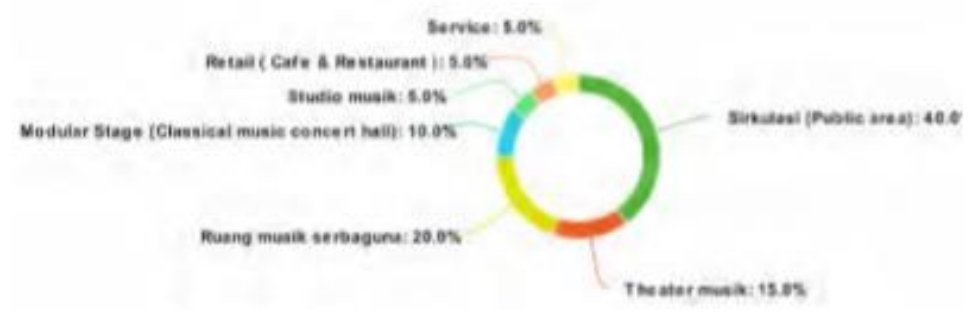

Gambar 10. Besaran Program Ruang Sumber: Penulis, 2019

Tabel 3. Alternatif Tapak

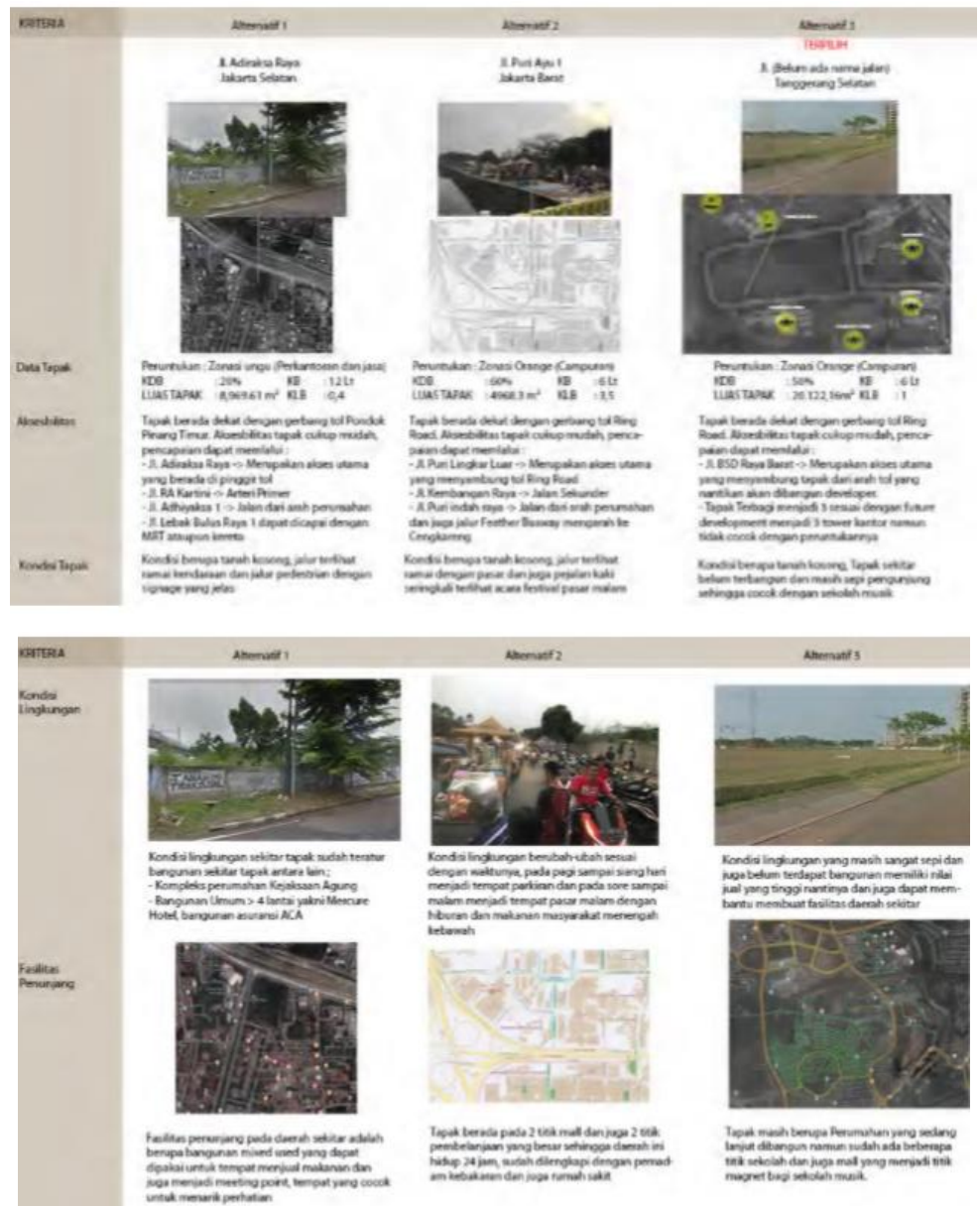

Sumber: Penulis, 2019 


\section{DISKUSI DAN HASIL}

Dari isu millennial yang dibahas, Program utama yang dipilih adalah sebuah komunitas musik, dikarenakan banyaknya masalah millennial yang belajar otodidak berdasarkan internet yang dipelajari oleh satu arah, tentunya satu arah dapat membuat informasi menjadi setengah. Komunitas musik diharapkan dapat menarik millennial terutama di daerah BSD dengan jumlah millennial paling banyak dapat bermain dan belajar Bersama. Dengan mengaplikasikan komunitas musik di Inggris yang sukses mendorong minat musik dengan menggambungkan sekelompok musisi sehingga mereka mempunyai sebuah tempat bermain dan belajar tentang hal baru dan juga musisi terkenal dapat mencurahkan berbagai pengalamannya. Sekolah musik untuk millennial memiliki ciri yang terbuka dan dibuat menjadi sebuah tempat informal dimana tempat tersebut dapat sharing ataupun belajar bersama tanpa adanya sistem formal.

Cara belajar menjadi berbeda dimana lebih banyak Studio besar bersama dibandingkan dengan studio kecil, tempat dimana mereka dapat berkumpul sharing bersama dalam sebuah taman oleh karena itu memerlukan sebuah tempat seperti amphitheater dimana mereka dapat bermain, menonton ataupun menjadi sebuah aktivitas komunitas Bersama. Dalam bentuk bangunan yang dihasilkan juga tidak hanya bentuk yang sembarangan karena dengan bentuk yang menarik dapat menambah jumlah peminat masyarakat untuk lebih mengetahui isi bangunan yang ada, oleh karena itu dalam tahap bangunan ini.

\section{KESIMPULAN DAN SARAN}

Komunitas musik dibuat untuk melengkapi keinginan millennial dimana mereka ingin sesuatu yang berbeda dari biasanya, seperti bebas untuk bermain, berkumpul ataupun bebas untuk belajar. Oleh karena itu diciptakan program tambahan menarik seperti modular stage dimana mereka dapat berkumpul untuk menonton, bermain, ataupun pentas kecil, juga kelaskelas besar lebih banyak dibandingkan kelas kecil. Auditoriumpun diperlukan untuk hal yang besar dimana mereka dapat mempelajari untuk terjun ke dunia profesional.

Dalam sebuah komunitas hal paling penting adalah menciptakan ruangan agar orang dapat tertarik dan ingin masuk dalam bangunan. Dengan menggabungkan program dari buku Pattern Languange diperlukan sebuah tempat seperti Retail, Tempat duduk, Lapangan terbuka dan juga Taman. Hal tersebut dimasukan untuk menjadi sebuah bangunan yang kompleks.

\section{REFERENSI}

Ali, H. (2016). Memahami Millenial Indonesia. Jakarta: Alvara Research Center.

Brinner, B. (1995-12-01). Knowing Music, Making Music: Javanese Gamelan and the Theory of Musical Competence and Interaction. University of Chicago Press. ISBN 978-0-226-07509-9.

Burns, J. M. (2009). Female Voices from an Ewe Dance-drumming Community in Ghana: Our Music Has Become a Divine Spirit. Ashgate Publishing, Ltd. ISBN 978-0-75466495-6. National Commission on Music Education (1991-01-01). Growing Up Complete: The Imperative for Music Education. R\&L Education. ISBN 978-0-940796-89-8.

Christopher, A. dkk. (1977). A Pattern Languange. United State, America

Colwell, R., Richardson, C. (2002-04-18). The New Handbook of Research on Music Teaching and Learning: A Project of the Music Educators National Conference. Oxford University Press, USA. ISBN 978-0-19-513884-9.

Denzin, N. K. (2010-10-11). Studies in Symbolic Interaction. Emerald Group Publishing. ISBN 978-0-85724-361-4.

Froehlich, M. A. (2004). 101 Ideas for Piano Group Class: Building an Inclusive Music Community for Students of All Ages and Abilities. Alfred Music. ISBN 978-1-4574-38851 
Nettl, B. (2005-11-10). The Study of Ethnomusicology: Thirty-one Issues and Concepts. University of Illinois Press.

Soraya, N. (2018). Jakarta Property Market Report. Jakarta: Colliers International Indonesia.

Veblen, K. K.; Elliott, David J.; Messenger, Stephen J.; Silverman, Marissa (2013). Community Music Today. Rowman \& Littlefield. ISBN 978-1-60709-319-0.

Waldron, J. (2009-12-01). "Exploring a virtual music community of practice: Informal music learning on the Internet". Journal of Music, Technology \& Education. Wolf, Mary Montgomery (2007). "Introduction". "We Accept You, One of Us?": Punk Rock, Community, and Individualism in an Uncertain Era, 1974-1985. ProQuest. ISBN 978-0-549-32581-9 